\title{
Distal Bile Duct Cancer pT3 TNM Finding v7
}

National Cancer Institute

\section{Source}

National Cancer Institute. Distal Bile Duct CancerpT3 TNM Finding v7. NCI Thesaurus.

Code C90251.

Distal bile duct cancer with tumor invading the gallbladder, pancreas, duodenum, or other adjacent organs without involvement of the celiac axis or the superior mesenteric artery. (from AJCC 7th Ed.) 